\title{
Do Older Adults With Reduced Bone Mineral Density Benefit From Strength Training? A Critically Appraised Topic
}

\author{
Maja Zamoscinska, Irene R. Faber, and Dirk Büsch
}

\begin{abstract}
Clinical Scenario: Reduced bone mineral density (BMD) is a serious condition in older adults. The mild form, osteopenia, is often a precursor of osteoporosis. Osteoporosis is a pathological condition and a global health problem as it is one of the most common diseases in developed countries. Finding solutions for prevention and therapy should be prioritized. Therefore, the critically appraised topic focuses on strength training as a treatment to counteract a further decline in BMD in older adults. Clinical Question: Is strength training beneficial in increasing BMD in older people with osteopenia or osteoporosis? Summary of Key Findings: Four of the 5 reviewed studies with the highest evidence showed a significant increase in lumbar spine BMD after strength training interventions in comparison with control groups. The fifth study confirmed the maintenance of lumbar spine density due to conducted exercises. Moreover, 3 reviewed studies revealed increasing BMD at the femoral neck after strength training when compared with controls, which appeared significant in 2 of them. Clinical Bottom Line: The findings indicate that strength training has a significant positive influence on BMD in older women (ie, postmenopausal) with osteoporosis or osteopenia. However, it is not recommended to only rely on strength training as the increase of BMD may not appear fast enough to reach the minimal desired values. A combination of strength training and supplements/medication seems most adequate. Generalization of the findings to older men with reduced BMD should be done with caution due to the lack of studies. Strength of Recommendation: There is grade B of recommendation to support the validity of strength training for older women in postmenopausal phase with reduced BMD.
\end{abstract}

Keywords: bone diseases, osteopenia, osteoporosis, resistance training, healthy aging

\section{Clinical Scenario}

Reduced bone mineral density (BMD) and as a consequence a reduced bone strength is a serious health impairment in older adults. ${ }^{1}$ Generally, 2 states within the reduction range of BMD are distinguished: osteopenia and osteoporosis. ${ }^{2,3}$ Osteopenia is the mild state in which BMD is decreased. ${ }^{2}$ This state is often considered to be a precursor or risk factor for developing osteoporosis ${ }^{2,3}$; therefore, it is comprehensibly called "borderline" osteoporosis. ${ }^{4}$ Osteoporosis, also known as bone loss, is a metabolic disease of the bone system, which is characterized by gradually decreasing bone mass and deteriorating microarchitecture of bone tissue..$^{1,4,5}$ People of all ages may develop reduced BMD, but the majority of patients are older females and males. ${ }^{5}$ This disorder may go unnoticed for years, and in many cases it is recognized only after the occurrence of painful fractures (eg, femoral neck, spinal, forearm, humerus, rib, and pelvic). ${ }^{1}$ These fractures often cause great suffering to people and thus severely limit their quality of life. ${ }^{1,4,5}$ Reduced BMD and specifically severe osteoporosis is a global health problem ${ }^{1,5-8}$; worldwide there are around 200 million people with osteoporosis. ${ }^{9}$ Obviously, women are more prone to suffer from reduced BMD than men (eg, osteoporosis prevalence ranged from $9 \%$ to $38 \%$ for women and $1 \%$ to $8 \%$ for men). ${ }^{10}$ Finding solutions to this health problem is a critical issue. Health promotion, prevention, and therapy should be prioritized.

Zamoscinska, Faber, and Büsch are with the Institute of Sport Science, University of Oldenburg, Oldenburg, Germany. Faber is also with the International Table Tennis Federation, Lausanne, Switzerland. Faber (irene.faber@uol.de) is corresponding author.
Although previously, reduced BMD was detected only when it led to the first bone fracture (ie, osteoporosis), today a person's BMD can be measured accurately and reliably using bone densitometry (dual-energy X-ray absorptiometry). ${ }^{11-13}$ Dual-energy $\mathrm{X}$-ray absorptiometry measures BMD in gram per square centimeter and provides a $T$ score, which is used as a proxy (ie, indirect measurement) for bone strength. ${ }^{1}$ Persons with $T$ scores between +1.0 and -1.0 are classified as healthy, while persons with $T$ scores between -1.0 and -2.5 are diagnosed with osteopenia and -2.5 or lower with osteoporosis. ${ }^{4,14}$ This method is recommended by the World Health Organization. ${ }^{11,14}$

If reduced BMD is recognized, the next step is to select a suitable and promising therapy to increase the BMD or prevent deterioration. ${ }^{1}$ In general, supplements and/or medicines are used as the main treatment. ${ }^{9}$ To be more precise, the basic treatment consists of supplementations with calcium and vitamin D. ${ }^{15}$ In addition, the patients often have to take antiresorptive or osteoanabolic medication. ${ }^{15,16}$ Although this treatment is beneficial, applying these medicines can cause one or more side effects (eg, kidney stones, bothersome gastrointestinal effects including bloating and constipation, cardiovascular disease, upper gastrointestinal irritation, flu-like illness, venous thromboembolism, and breast cancer). ${ }^{17,18}$ The consequence of these side effects is the frequent decision to end the necessary treatment. ${ }^{17,18}$ Therefore, it seems sensible to search for an alternative solution to treat reduced BMD with less or without negative side effects.

One of the proposed alternatives to supplements/medicine is strength training. ${ }^{9,19}$ Strength training indeed is suggested to counteract the degeneration of bone substance, especially in older adults. ${ }^{20}$ Besides that, it improves muscle strength and coordination skills, therefore, supports the preservation of stability, which is important factor in the prevention of falling. ${ }^{20,21}$ Strength training 
can also increase the resilience of tendons, ligaments, and joints. ${ }^{22}$ Furthermore, it leads to higher efficiency of the cardiovascular and immune system. ${ }^{22,23}$ Last but not least, it is believed to relieve pain and improves mood and well-being. ${ }^{23,24}$ For all these reasons, it might have a very positive influence on the quality of life. However, the advantages of strength training seem apparent and no disadvantages are mentioned so far, it is largely unknown whether strength training can be a reasonable treatment option to increase BMD in older adults suffering from osteoporosis or osteopenia. ${ }^{25}$ For that reason, recent literature was explored to find an answer to the following question.

\section{Focused Clinical Question}

Is strength training beneficial in increasing BMD in older people with osteopenia or osteoporosis?

\section{Summary of Search, "Best Evidence" Appraised, and Key Findings}

- The literature was searched for studies of level 3 evidence or higher that investigated the effect of strength training on BMD in older adults with reduced BMD (ie, osteoporosis or osteopenia) in July 2019.

- The search of the literature yielded 14 possible studies for inclusion.

- Five studies ${ }^{26-30}$ met the inclusion criteria and were critically appraised using the 27-item modified Downs and Black checklist $^{31}$ in which individual studies were categorized as excellent (26-28/28), good (20-25/28), fair (15-19/28), or poor $(\leq 14 / 28)$ quality (Appendix 1$).{ }^{32}$

- Four of the 5 reviewed studies ${ }^{26-28,30}$ showed a significant increase in lumbar spine BMD after strength training interventions in comparison with control groups (lack of strength training).

- The fifth study ${ }^{29}$ confirmed maintaining of lumbar spine BMD due to conducted exercises.

- Three reviewed studies ${ }^{26,29,30}$ showed that strength training interventions increased femoral neck BMD in comparison with control. However, a significant increase was noted only in 2 of them. ${ }^{26,30}$

\section{Clinical Bottom Line}

There is a grade B of recommendation to support the validity of strength training as a means to increase BMD in older women with osteoporosis or osteopenia ${ }^{26-30}$; therefore, it should be considered as a clinical option for increasing BMD and reducing the negative effects. Furthermore, the review of the studies suggests that the amount of exercise per week and the intensity of the training are important issues of strength training (Table 1). Research by BorbaPinheiro et $\mathrm{al}^{26}$ indicated that the same strength training program executed 3 times a week was significantly more efficient compared with the same training for 2 times a week. Furthermore, Watson et $\mathrm{al}^{30}$ showed that a difference in intensity of the training (high intensity vs low intensity) led to difference in BMD improvement; more intensity in training was followed by a larger improvement in BMD (Table 1). Although the systematic search did not exclude any sex, it showed lack of studies on older men with reduced BMD and therefore generalization of the outcomes to this target group should be done with caution. Despite the promising results, indicating strength training as the only treatment is not recommended at this moment. The BMD may not increase fast enough to reach the desired level so that further examinations with strength training and supplements/medicine are needed to confirm this approach.

\section{Strength of Recommendation}

According to The Centre for Evidence-Based Medicine Levels of Evidence 2011, ${ }^{33}$ there is a grade B of recommendation to support validity of strength training for older women with reduced BMD. This recommendation is based on level 2 of evidence with sufficient consistent findings shown by reviewed studies.

\section{Search Strategy}

\section{Terms Used to Guide Search Strategy}

- Patient/Client group: older adults with reduced BMD

- Intervention: strength training

- Comparison: lack of strength training

- Outcome: change in BMD

Literature was searched in July 2019 by using combinations of the terms: "osteoporosis" OR "osteopenia" OR "bone loss" (P) AND "strength training" OR "resistance training" (I) AND "bone density" OR "BMD” (O). Titles, abstracts, and/or full texts were used to check for the inclusion and exclusion criteria.

\section{Sources of Evidence Searched}

- PubMed

- Web of Science

- Scopus

\section{Inclusion and Exclusion Criteria}

\section{Inclusion Criteria}

- Studies only on older adults (for women this meant to include only those who are in the postmenopausal phase) with reduced BMD (ie, osteoporosis or osteopenia)

- Studies that investigated strength training interventions

- Limited to publications from 2004 to 2019 in the English language

\section{Exclusion Criteria}

- Studies that investigated healthy subjects

- Studies that investigated subjects with other diseases

- Studies that did not measure BMD changes

- Studies without control group (lack of strength training intervention)

\section{Results of Search}

Five relevant studies ${ }^{26-30}$ were included after determining eligibility and categorized as presented in Table 2 (based on Levels of Evidence, The Centre for Evidence-Based Medicine, 2011). ${ }^{33}$ 


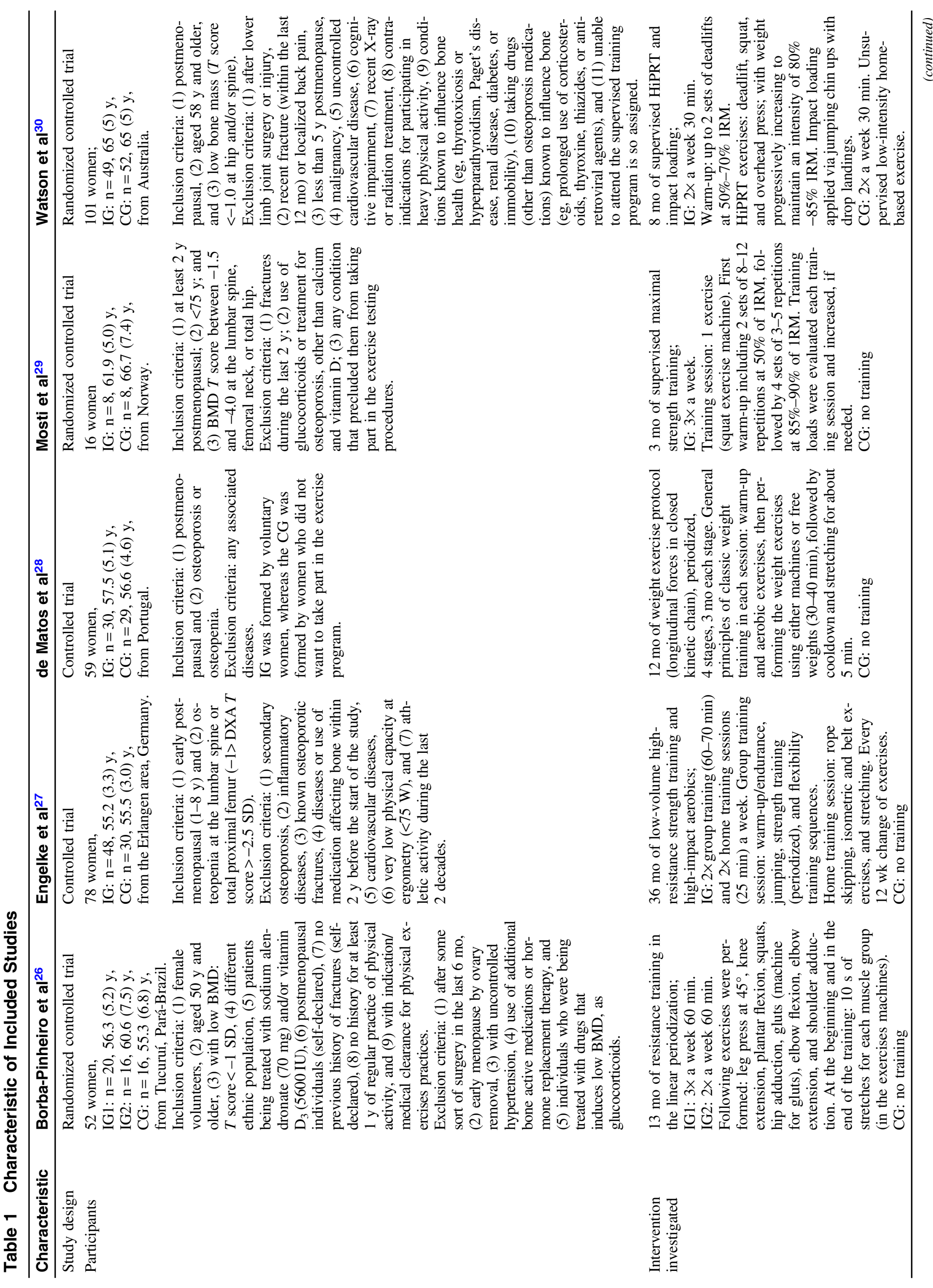




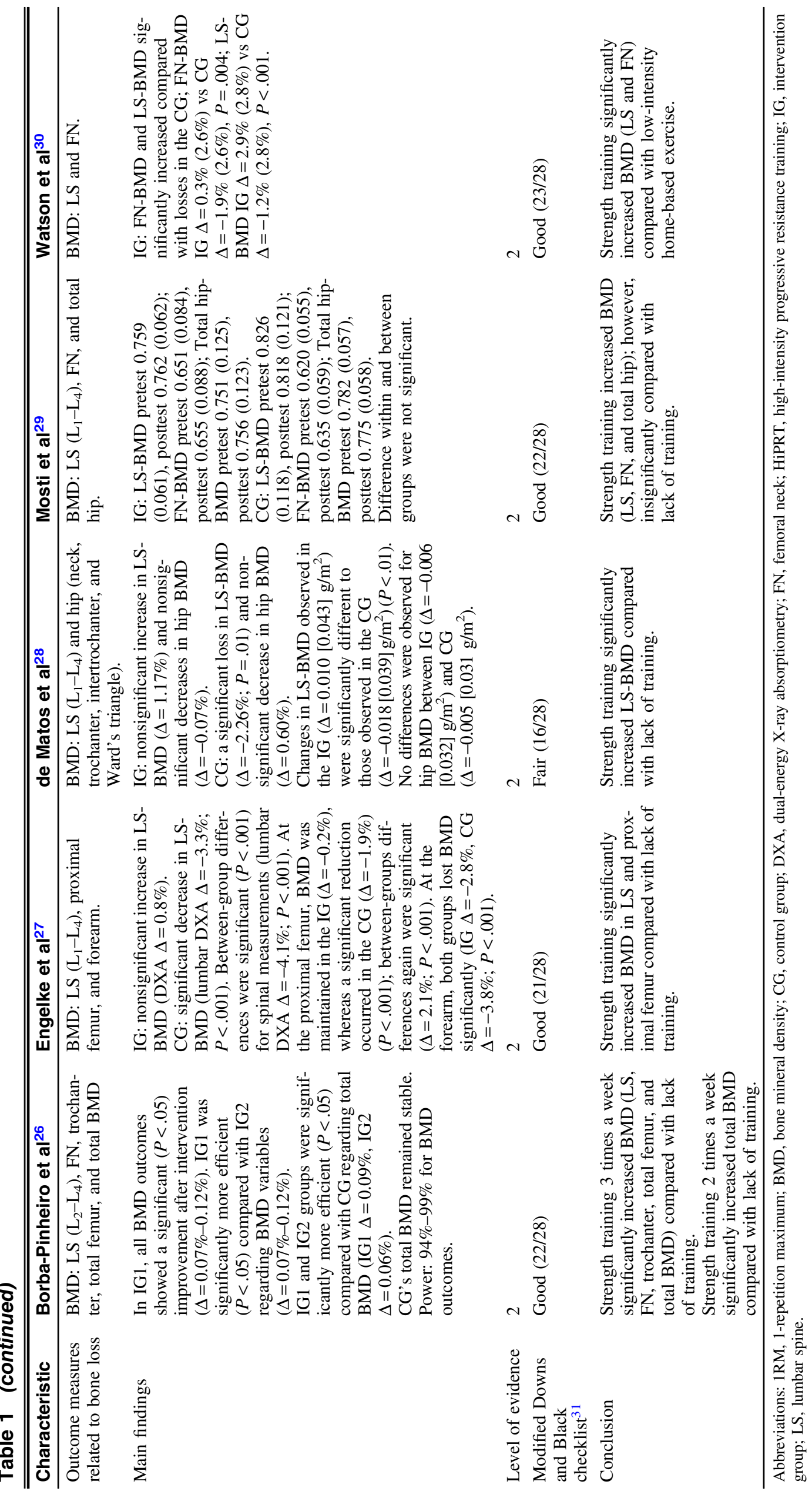


Table 2 Summary of Study Designs and Level of Evidence Based on CEBM $2011^{33}$

\begin{tabular}{llcl}
\hline Level of evidence & \multicolumn{1}{c}{ Study design } & Number located & \multicolumn{1}{c}{ References } \\
\hline 2 & Randomized controlled trial & 3 & $\begin{array}{l}\text { Borba-Pinheiro et al }{ }^{26} \\
\text { Mosti et al }{ }^{29} \\
\text { Watson et al }\end{array}$ \\
2 & Controlled trial & 2 & $\begin{array}{l}\text { Engelke et al } \\
\text { de Matos et al }{ }^{28}\end{array}$ \\
\hline
\end{tabular}

Abbreviation: CEBM, Centre for Evidence-Based Medicine.

\section{Best Evidence}

The studies in Table 2 were identified as best evidence and selected for inclusion in this critically appraised topic. These studies were included, because they measured the change in BMD after strength training intervention in older adults with osteoporosis or osteopenia and comparing with BMD changes in control group.

\section{Implications for Practice, Education, and Future Research}

The research reviewed in this critically appraised topic indicated that strength training is an effective therapy to increase BMD in older women with osteoporosis or osteopenia. ${ }^{26-30}$ It also led to establishing the following implications for practice. Based on the results of the included studies it appears that the most beneficial is applying of strength training 2 to 3 times a week. ${ }^{26}$ The favorable length of the training is estimated between 30 and 60 minutes; this depends on the intensity and volume of given workout program (Table 1). Incorporation of these guidelines into a training program should lead to the increasing of BMD. ${ }^{26-30}$ Strength training of lower intensity, volume, or timeframe might not increase BMD significantly, but can contribute to the maintenance of a certain level. ${ }^{34}$

At this point, it is important to emphasize that in case of strength training, a crucial element are the resistance level and the nature of the training itself. ${ }^{9}$ To impact muscles and bones sufficiently to prospectively increase $\mathrm{BMD}$, the resistance level of strength training has to be a minimum of $70 \%$ of 1-repetition maximum or at least "moderate intensity."12,13,35 This was also confirmed by research included here (Table 1). However, it is important to consider the level of experience when selecting adequate resistance level of the training. ${ }^{9}$ Starting a training program with inadequate resistance level of the training would be irresponsible and potentially dangerous behavior, especially in older adults with reduced BMD. ${ }^{25}$ Beginners should start with muscle endurance training (ie, lower resistance levels and higher number of repetitions). ${ }^{36}$ Following increase of the intensity combined with the reduction of the repetition number results with a transition to hypertrophy training and finally maximal strength training. ${ }^{36}$ The nature of the training should provide an osteogenic effect on bones. ${ }^{37}$ Muscle actions (muscle loading) and impact forces (gravitational loading) are mechanical forces acting on the skeleton and causing metabolic response in bone tissue. ${ }^{38}$ Aquatic exercises (eg, swimming) or cycling reduce the gravity force affecting the body making them convenient for older adults, but provide no or not enough impact on bone (no impact activity). ${ }^{8,39,40}$ Therefore, these exercises are not useful as means of complementing the treatment of osteoporosis or even preventive measure. . $^{8,39,40}$ The studies included in this critically appraised topic showed the relevance of impact loading and high-intensity exercises on bone stimulation. It has been proven that they are not only safe, but also sufficient to improve BMD. ${ }^{26-30}$

Some limitations of this study needs to be acknowledged. First, an important fact to mention is the lack of studies on older men with reduced BMD. A different response in older men after strength training intervention might exist, because they have significantly more muscle tissue $( \pm 25 \%)$ and muscular strength $( \pm 30 \%)$ than their female peers. ${ }^{41}$ Second, no studies were found that focus on strength training as an alternative for medication therapy in older adults with reduced BMD. For this, a randomized controlled trial is needed including 4 groups (ie, intervention and control groups with and without medication intake) in the best case with a large representative number of subjects. Third, the included studies did not all provide similar outcomes and the effect sizes of their results. Reporting similar outcomes, the effect sizes or estimated thereof would facilitate the interpretation of treatment effect. Finally, although our literature search was conducted in 3 prominent databases, a more extensive search covering more databases is recommended for future searches.

This critically appraised topic showed level B evidence that strength training has a positive and significant influence on bone density in older female adults with reduced BMD. In addition, it seems worth mentioning that it also has a positive effect on strength gain, pain reduction, functional autonomy, and quality of life. ${ }^{26,27,29,30}$ However, it is not recommended to only rely on strength training to increase bone density at this moment. The BMD may not increase fast enough to reach a sufficient value. A combination of strength training and supplements/medication seems most adequate but further examinations are needed to be able to recommend differently. This critically appraised topic should be reviewed in approximately 2 years (2021) to determine if there is any additional best evidence that may alter the practical bottom line for this clinical question.

\section{Acknowledgments}

There were no sources of funding to support this critically appraised topic. The authors report no conflicts of interest directly related to this critically appraised topic.

\section{References}

1. Cosman F, de Beur SJ, LeBoff MS, et al. Clinician's guide to prevention and treatment of osteoporosis. Osteoporos Int. 2014;25(10):2359-2381. PubMed ID: 25182228 doi:10.1007/ s00198-014-2794-2

2. Pasco JA, Seeman E, Henry MJ, et al. The population burden of fractures originates in women with osteopenia, not osteoporosis. 
Osteoporos Int. 2006;17(9):1404-1409. PubMed ID: 16699736 doi:10.1007/s00198-006-0135-9

3. Karaguzel G, Holick MF. Diagnosis and treatment of osteopenia. Rev Endocr Metab Disord. 2010;11(4):237-251. PubMed ID: 21234807 doi:10.1007/s11154-010-9154-0

4. Bartl R, Frisch B. Osteoporosis: Diagnosis, Prevention, Therapy. 2nd ed. Berlin: Springer Berlin Heidelberg; 2009.

5. Hernlund E, Svedbom A, Ivergård $\mathrm{M}$, et al. Osteoporosis in the European Union: medical management, epidemiology and economic burden. Arch Osteoporos. 2013;8:136. PubMed ID: 24113837 doi:10.1007/s11657-013-0136-1

6. Choi HS, Park SY, Kim YM, et al. Medical treatment of severe osteoporosis including new concept of advanced severe osteoporosis. Osteoporos Sarcopenia. 2016;2(1):13-19. PubMed ID: 30775462 doi:10.1016/j.afos.2016.02.003

7. Wright NC, Looker AC, Saag KG, et al. The recent prevalence of osteoporosis and low bone mass in the United States based on bone mineral density at the femoral neck or lumbar spine. $J$ Bone Miner Res. 2014;29(11):2520-2526. PubMed ID: 24771492 doi:10.1002/ jbmr.2269

8. Hadji P, Klein S, Gothe H, et al. The epidemiology of osteoporosisbone evaluation study (BEST). An analysis of routine health insurance data. Dtsch Arztebl Int. 2013; 110(4):52-57. PubMed ID: 23413388 doi:10.3238/arztebl.2013.0052

9. Moreira LDF, de Oliveira ML, Lirani-Galvão AP, et al. Physical exercise and osteoporosis: effects of different types of exercises on bone and physical function of postmenopausal women. Arq Bras Endocrinol Metabol. 2014;58(5):514-522. PubMed ID: 25166042 doi:10.1590/0004-2730000003374

10. Wade SW, Strader C, Fitzpatrick LA, Anthony MS, O'Malley CD. Estimating prevalence of osteoporosis: examples from industrialized countries. Arch Osteoporos. 2014;9:182. PubMed ID: 24847682 doi:10.1007/s11657-014-0182-3

11. Wilson DJ. Osteoporosis and sport. Eur J Radiol. 2019;110:169-174. PubMed ID: 30599856 doi:10.1016/j.ejrad.2018.11.010

12. Calatayud J, Borreani S, Moya D, Colado JC, Triplett NT. Exercise to improve bone mineral density. Strength Cond J. 2013;35(5), 70-74. doi:10.1519/SSC.0b013e3182980d57

13. Calatayud J, Borreani S, Moya D, Colado JC, Triplett NT. Exercise to improve bone mineral density (Erratum). Strength Cond J. 2013;35(6), 58. doi:10.1519/SSC.0000000000000023

14. Pontes TA, Barbosa AD, Silva RD, Melo-Junior MR, Silva RO. Osteopenia-osteoporosis discrimination in postmenopausal women by ${ }^{1}$ H NMR-based metabonomics. PLoS One. 2019;14(5):e0217348. PubMed ID: 31141566 doi:10.1371/journal.pone.0217348

15. Gallagher JC, Tella SH. Prevention and treatment of postmenopausal osteoporosis. J Steroid Biochem Mol Biol. 2014;142:155-170. PubMed ID: 24176761 doi:10.1016/j.jsbmb.2013.09.008

16. Tu KN, Lie JD, Wan CKV, et al. Osteoporosis: a review of treatment options. $P$ T. 2018;43(2):92-104. PubMed ID: 29386866

17. Reid IR. Efficacy, effectiveness and side effects of medications used to prevent fractures. J Intern Med. 2015;277:690-706. PubMed ID: 25495429 doi:10.1111/joim.12339

18. Lindsay BR, Olufade T, Bauer J, Babrowicz J, Hahn R. Patientreported barriers to osteoporosis therapy. Arch Osteoporos. 2016;11:19. PubMed ID: 27129487 doi:10.1007/s11657-016-0272-5

19. Zhao R, Zhao M, Xu Z. The effects of differing resistance training modes on the preservation of bone mineral density in postmenopausal women: a meta-analysis. Osteoporos Int. 2015;26(5):1605-1618. PubMed ID: 25603795 doi:10.1007/s00198-015-3034-0

20. Senderovich H, Tang H, Belmont S. The role of exercises in osteoporotic fracture prevention and current care gaps. Where are we now? Recent updates. Rambam Maimonides Med J. 2017;8(3): e0032. PubMed ID: 28786812 doi:10.5041/RMMJ.10308

21. Hsu WL, Chen CY, Tsauo JY, Yang RS. Balance control in elderly people with osteoporosis. J Formos Med Assoc. 2014;113(6):334339. PubMed ID: 24650494 doi:10.1016/j.jfma.2014.02.006

22. Tieland M, Trouwborst I, Clark BC. Skeletal muscle performance and ageing. J Cachexia Sarcopenia Muscle. 2018;9(1):3-19. PubMed ID: 29151281 doi:10.1002/jcsm. 12238

23. Daley MJ, Spinks WL. Exercise, mobility and aging. Sports Med. 2000;29(1):1-12. PubMed ID: 10688279 doi:10.2165/00007256200029010-00001

24. Tod D, Lavallee D, eds. The Psychology of Strength and Conditioning. London: Routledge; 2012.

25. Benedetti MG, Furlini G, Zati A, Letizia Mauro G. The effectiveness of physical exercise on bone density in osteoporotic patients. Biomed Res Int. 2018;23:4840531. PubMed ID: 30671455 doi:10.1155/2018/ 4840531

26. Borba-Pinheiro CJ, Carvalho MC, Dantas EH, et al. Resistance training programs on bone related variables and functional independence of postmenopausal women in pharmacological treatment: a randomized controlled trial. Arch Gerontol Geriatr. 2016;65:36-44. PubMed ID: 26956618 doi:10.1016/j.archger.2016.02.010

27. Engelke K, Kemmler E, Lauber E, et al. Exercise maintains bone density at spine and hip EFOPS: a 3-year longitudinal study in early postmenopausal women. Osteoporos Int. 2006;17:133-142. PubMed ID: 16096715 doi:10.1007/s00198-005-1938-9

28. de Matos O, Lopes da Silva D, de Oliveira JM, Castelo-Branco C. Effect of specific exercise training on bone mineral density in women with postmenopausal osteopenia or osteoporosis. Gynecol Endocrinol. 2009;25(9):616-620. PubMed ID: 19533480 doi:10.1080/ 09513590903015593

29. Mosti MP, Kaehler N, Stunes AK, Hoff J, Syversen U. Maximal strength training in postmenopausal women with osteoporosis or osteopenia. J Strength Cond Res. 2013;27(10):2879-2886. PubMed ID: 23287836 doi:10.1519/JSC.0b013e318280d4e2

30. Watson SL, Weeks BK, Weis LJ, et al. High-intensity resistance and impact training improves bone mineral density and physical function in postmenopausal women with osteopenia and osteoporosis: the LIFTMOR randomized controlled trial. J Bone Miner Res. 2018;33(2):211-220. PubMed ID: 28975661 doi:10.1002/jbmr.3284

31. Downs SH, Black N. The feasibility of creating a checklist for the assessment of the methodological quality both of randomised and non-randomised studies of health care interventions. $J$ Epidemiol Community Health. 1998;52(6):377-384. PubMed ID: 9764259 doi:10.1136/jech.52.6.377

32. Hooper P, Jutai JW, Strong G, Russell-Minda E. Age-related macular degeneration and low-vision rehabilitation: a systematic review. Can J Ophthalmol. 2008;43(2):180-187. PubMed ID: 18347620 doi:10. 3129/i08-001.

33. OCEBM Levels of Evidence Working Group. The Oxford 2011 Levels of Evidence. Oxford Centre for Evidence-Based Medicine. http://www.cebm.net/index.aspx?o=5653. Updated May 1, 2016. Accessed March 14, 2019

34. Morton RW, Colenso-Semple L, Phillips SM. Training for strength and hypertrophy: an evidence-based approach. Curr Opin Physiol. 2019;10:90-95. doi:10.1016/j.cophys.2019.04.006

35. Mosti MP, Carlsen T, Aas E, et al. Maximal strength training improves bone mineral density and neuromuscular performance in young adult women. J Strength Cond Res. 2014;28(10):2935-2945. PubMed ID: 24736773 doi:10.1519/JSC.0000000000000493

36. Rippetoe M, Baker A. Practical Programming for Strength Training. 3rd ed. Wichita Falls, TX: The Aasgaard Company; 2014. 
37. Santos L, Elliott-Sale KJ, Sale C. Exercise and bone health across the lifespan. Biogerontology. 2017;18(6):931-946. PubMed ID: 29052784 doi:10.1007/s10522-017-9732-6

38. Kohrt WM, Barry DW, Schwartz RS. Muscle forces or gravity: what predominates mechanical loading on bone? Med Sci Sports Exerc. 2009;41(11):2050-2055. PubMed ID: 19812511 doi:10.1249/MSS. 0b013e3181a8c717

39. Klomsten Andersen O, Clarsen B, Garthe I, Mørland M, Stensrud T. Bone health in elite Norwegian endurance cyclists and runners: a cross-sectional study. BMJ Open Sport Exerc Med. 2018; 4(1):e000449. PubMed ID: 30687513 doi:10.1136/bmjsem-2018000449

40. Abrahin O, Rodrigues RP, Marçal AC, et al. Swimming and cycling do not cause positive effects on bone mineral density: a systematic review. Rev Bras Reumatol Engl Ed. 2016;56(4):345-351. PubMed ID: 27476628 doi:10.1016/j.rbre.2016.02.013

41. Fleck SJ, Kraemer WJ. Designing Resistance Training Programs. 4th ed. Champaign, IL: Human Kinetics; 2014. 


\begin{tabular}{|c|c|c|c|c|c|c|}
\hline & & $\begin{array}{l}\text { Borba-Pinheiro } \\
\quad \text { et } \mathrm{al}^{26}\end{array}$ & $\begin{array}{l}\text { Engelke } \\
\text { et } \text { al }^{27}\end{array}$ & $\begin{array}{l}\text { de Matos } \\
\text { et } \mathrm{al}^{28}\end{array}$ & $\begin{array}{l}\text { Mosti } \\
\text { et } \mathbf{a l}^{29}\end{array}$ & $\begin{array}{l}\text { Watson } \\
\text { et } \mathbf{a l}^{30}\end{array}$ \\
\hline \multicolumn{7}{|c|}{ REPORTING } \\
\hline 1 & $\begin{array}{l}\text { Hypothesis/aim/objective clearly } \\
\text { described }\end{array}$ & 1 & 1 & 1 & 1 & 1 \\
\hline 2 & $\begin{array}{l}\text { Main outcomes in Introduction/ } \\
\text { Methods clearly described }\end{array}$ & 1 & 1 & 1 & 1 & 1 \\
\hline 3 & $\begin{array}{l}\text { Patient characteristics clearly } \\
\text { described }\end{array}$ & 1 & 1 & 1 & 1 & 1 \\
\hline 4 & $\begin{array}{l}\text { Interventions of interest clearly } \\
\text { described }\end{array}$ & 1 & 1 & 1 & 1 & 1 \\
\hline 5 & $\begin{array}{l}\text { Principal confounders in each } \\
\text { group of subjects to be compared } \\
\text { clearly described }\end{array}$ & 2 & 2 & 2 & 1 & 2 \\
\hline 6 & Main findings clearly described & 1 & 1 & 1 & 1 & 1 \\
\hline 7 & $\begin{array}{l}\text { Estimates of random variability } \\
\text { provided for main outcomes }\end{array}$ & 1 & 1 & 1 & 1 & 1 \\
\hline 8 & $\begin{array}{l}\text { All adverse events of intervention } \\
\text { reported }\end{array}$ & 1 & 1 & 1 & 1 & 1 \\
\hline 9 & $\begin{array}{l}\text { Characteristics of patients lost to } \\
\text { follow-up described }\end{array}$ & 1 & 1 & 0 & 1 & 1 \\
\hline 10 & $\begin{array}{l}\text { Actual probability values reported } \\
\text { for main outcomes }\end{array}$ & 0 & 1 & 1 & 1 & 1 \\
\hline \multicolumn{7}{|c|}{ EXTERNAL VALIDITY } \\
\hline 11 & $\begin{array}{l}\text { Subjects asked to participate were } \\
\text { representative of source } \\
\text { population }\end{array}$ & 0 & 0 & 0 & 0 & 0 \\
\hline 12 & $\begin{array}{l}\text { Subjects prepared to participate } \\
\text { were representative of source } \\
\text { population }\end{array}$ & 0 & 0 & 0 & 0 & 0 \\
\hline 13 & $\begin{array}{l}\text { Staff, places, and facilities of } \\
\text { treatment were representative of } \\
\text { source population }\end{array}$ & 1 & 1 & 1 & 1 & 1 \\
\hline \multicolumn{7}{|c|}{$\begin{array}{l}\text { INTERNAL } \\
\text { VALIDITY-BIAS }\end{array}$} \\
\hline 14 & $\begin{array}{l}\text { Study participants blinded to } \\
\text { treatment }\end{array}$ & 0 & 0 & 0 & 0 & 0 \\
\hline 15 & Blinded outcome assessment & 0 & 0 & 0 & 0 & 1 \\
\hline 16 & $\begin{array}{l}\text { Any data dredging clearly } \\
\text { described }\end{array}$ & 1 & 1 & 1 & 1 & 1 \\
\hline 17 & $\begin{array}{l}\text { Analyses adjust for differing } \\
\text { lengths of follow-up }\end{array}$ & 1 & 1 & 1 & 1 & 1 \\
\hline 18 & $\begin{array}{l}\text { Appropriate statistical tests } \\
\text { performed }\end{array}$ & 1 & 1 & 1 & 1 & 1 \\
\hline 19 & $\begin{array}{l}\text { Compliance with interventions } \\
\text { was reliable }\end{array}$ & 1 & 1 & 1 & 1 & 1 \\
\hline 20 & $\begin{array}{l}\text { Outcome measures were reliable } \\
\text { and valid }\end{array}$ & 1 & 1 & 1 & 1 & 1 \\
\hline \multicolumn{7}{|c|}{$\begin{array}{l}\text { INTERNAL } \\
\text { VALIDITY_CONFOUNDING }\end{array}$} \\
\hline 21 & $\begin{array}{l}\text { All participants recruited from the } \\
\text { same source population }\end{array}$ & 1 & 1 & 0 & 1 & 1 \\
\hline 22 & $\begin{array}{l}\text { All participants recruited over the } \\
\text { same time period }\end{array}$ & 1 & 1 & 0 & 0 & 1 \\
\hline
\end{tabular}


(continued)

\begin{tabular}{|c|c|c|c|c|c|c|}
\hline & & $\begin{array}{c}\text { Borba-Pinheiro } \\
\text { et } \mathrm{al}^{26}\end{array}$ & $\begin{array}{c}\text { Engelke } \\
\text { et } \mathrm{al}^{27}\end{array}$ & $\begin{array}{l}\text { de Matos } \\
\text { et } \mathrm{al}^{28}\end{array}$ & $\begin{array}{l}\text { Mosti } \\
\text { et } a^{29}\end{array}$ & $\begin{array}{l}\text { Watson } \\
\text { et } \mathrm{al}^{30}\end{array}$ \\
\hline 23 & $\begin{array}{l}\text { Participants randomized to } \\
\text { treatment }\end{array}$ & 1 & 0 & 0 & 1 & 1 \\
\hline 24 & $\begin{array}{l}\text { Allocation of treatment concealed } \\
\text { from investigators and } \\
\text { participants }\end{array}$ & 0 & 0 & 0 & 0 & 0 \\
\hline 25 & $\begin{array}{l}\text { Adequate adjustment for } \\
\text { confounding }\end{array}$ & 1 & 1 & 0 & 1 & 1 \\
\hline 26 & $\begin{array}{l}\text { Losses to follow-up taken into } \\
\text { account }\end{array}$ & 1 & 1 & 0 & 1 & 1 \\
\hline \multicolumn{7}{|l|}{ POWER } \\
\hline 27 & $\begin{array}{l}\text { Sufficient power to detect treat- } \\
\text { ment effect at a significance level } \\
\text { of } .05\end{array}$ & 1 & 0 & 0 & 1 & 0 \\
\hline TOTAL SCORE & & $22 / 28$ & $21 / 28$ & $16 / 28$ & $22 / 28$ & $23 / 28$ \\
\hline
\end{tabular}

Note: 2 =yes (applies only to point 5 ); $1=$ yes; $0=$ no or unable to determine. Score range: $28-26$ excellent; $25-20$ good; $19-15$ fair; $\leq 14$ poor. ${ }^{21}$ 